\section{1. 頭蓋頸椎移行部の解剖と神経症候}

和歌山県立医科大学医学部脳神経外科

今栄 信治, 北山 真理, 三木潤一郎, 大川都史香, 板倉 徹

頭蓋頸椎移行部は，椎骨動脈，延髄，頸髄，下位脳神経が 存在し，それらを保護すべく後頭骨，環椎，軸椎の 3 者が一 つの複合体を形成し，前後屈，回旋，外側屈曲など複雑な動 きを可能にしている，したがって，頭蓋頸椎移行部の病変を 扱う場合, これらの構築に障害が出ないアプローチを選択す ることが第一である。一方，手術アプローチにてやむなく構 築に破綻をきたし不安定性が生じた場合や，炎症，外傷など によって同様の不安定性を生じた場合は, 内固定手術を考慮 する必要がある，今回，これらの手術アプローチや固定手技 に必要な機能的解剖を, 周辺の勒帯, 筋の軟部組織も含めて 紹介したい. また, 疾患により異なるが, 頭蓋頸椎移行部の 神経症状は, 大孔部にスペースが多いため比較的ゆっくりと 進行すること, 病変レベルと神経症状が一致しない, いわゆ る false localizing sign を示すことなどが多い.これらのこと を踏まえ，延髄，上位頸髄，下位脳神経は当然のことながら， 第 1 および第 2 頸神経根も含めた疾患別の代表的神経症状 についても言及する。

\section{2. キアリ奇形の外科治療}

東京慈恵会医科大学脳神経外科

谷諭, 阿部 俊昭, 磯島 晃, 長島 弘泰, 日下康子

キアリ奇形は, 頭蓋頸椎移行部奇形性疾患ではよくみられ るものである。しかし，その病因に不明な点があることと春 䯣空洞症や頭蓋底陥入症などの奇形を合併することから，手 術戦略も画一的ではない. 一般には, 頭蓋頸椎移行部の䯣液 循環障害により発生する脊髄空洞症の合併の有無にかかわら ず，キアリ奇形に対する手術が行われる。これにはキアリ奇 形の基礎病態と考えられている減少した後頭蓋窩の容積の拡 大を目指すものと，あくまでも一番の責任病巣である狭小化 した大孔部の減圧を目指すものがある.このセッションでは, 大孔部減圧術のバリエーションの紹介と，われわれが行って いる手術術式のビデオ供覧を行う。一方, 頭蓋底陥入症を合 併したキアリ奇形においては，どの程度の前方病変がある時 に, 後方からの大孔部減圧の限界があるのか一定の見解を得 ていない，われわれは前方病変の程度にかかわらず，後方よ りの減圧を第一選択としてきたが，これにより二期的な手術 に至った症例は経験していない.しかし，前方病変に対する 次なる手術戦略の理解は必要であるので紹介をしたい.

\section{3. 大孔部腫瘍の外科治療}

大津市民病院脳神経外科

簤子丸 稔

大孔部腫瘍は, 前方は斜台下 3 分の 1 から軸椎椎体上縁ま での間, 側方は頸静脈結節から軸椎椎弓上縁までの間, 後方 は後頭鱗から軸椎棘突起までの間に存在する腫瘍であるが,

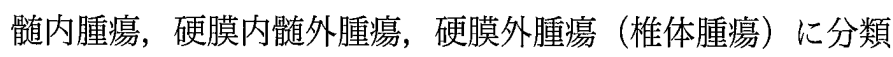
するとわかりやすい，大孔部の䯣内腫貆は脊髄䯣内腫瘍と同 様の性質を持ち，良性のものが多い，例えば，大孔部の上衣 腫は中心管沿いに発生し延髄との境界は明瞭で全摘出可能で あり, 発生母地に腫瘍が残存して再発しやすい第四脳室の上 衣腫と対照的である。大孔部の硬膜内髄外腫愓の多くは䯣膜 腫であるが，比較的大きくなってから発見される．前方ある いは側方に存在する髄膜腫の摘出にあたっては, 椎骨動脈と 下位脳神経との剶離に注意する必要がある. $\mathrm{C} 2$ 神経根から発 生する神経鞘腫の多くは, 硬膜外から神経組織を圧迫するが, 硬膜外の操作で豊富な静脈叢からの出血に兴まされる場合が ある. 椎体腫瘍の摘出後には後頭骨と頸椎の間の固定を必要 とすることがある. 大孔部腫瘍の摘出にあたっては, 解剖と 腫湯の特性を十分把握しておく必要がある.

\section{4. 脊髓動静脈奇形の診断と治療}

北海道大学医学部神経病態学講座神経外科

飛驒 一利, 矢野 俊介, 岩㠃 喜信

脊髄動静脈奇形は, 動静脈短絡の局在部位により, 髄内動 静脈奇形, 脊髄辺縁部動静脈㾞, 脊髄硬膜動静脈㾞の 3 つに 分類するのが, 治療を考えるうえで有用である. 脊髄動静脈 奇形を疑う際にまず行う検查がMRIであるが, 特徴的所見と して flow-void がある.これは, 拡張した流入動脈, 流出静 脈, nidus, 静脈瘤などの血管構造物を示している. MRAは 脊髄動静脈奇形の診断および経過観察に有用であり, dynamic CT および 3D DSA は, 脊髄動静脈奇形の鑑別診断あ るいは塞栓術の治療の判定のうえで有用な診断方法である. 現在, 脊髄辺縁部動静脈㜢に対しては, 観血的手術を主とし て行っており, 脊髄硬膜動静脈㾞は第一選択を人工塞栓術と し, 塞栓術が risk ある場合, あるいは十分な効果が得られな い場合に観血的手術を行っている。髄内動静脈奇形は依然と して治療が難しい場合が多く，人工塞栓術による治療が主と なるが, 最近では定位的放射線照射を行い, 良好な結果を得 ている，以上，脊髄動静脈奇形における診断と治療の要点に ついて言及する予定である。 